Kirsti Klette

University of Oslo

Karen Hammerness

American Museum of Natural History

Inga Staal Jenset

University of Oslo

DOI: http://dx.doi.org/10.5617/adno.4730

\title{
Established and evolving ways of linking to practice in teacher education: Findings from an international study of the enactment of practice in teacher education
}

\begin{abstract}
Worldwide, teacher educators and policymakers call for teacher preparation that is more deeply linked to practice. Yet, we know little about how such linkages are achieved within different international programs. We examine the degree to which programs provide opportunities to learn that are grounded in practice. We report on survey data $(n=486$ teacher candidates) from five programs in Finland, Norway, California, Chile, and Cuba, and observation data from the methods courses ( $n=104$ hours) in six programs in Finland, Norway, and California. Using an analytical framework decomposing the conception of 'opportunities that are grounded in practice' in teacher education, this article provides evidence regarding the successes-and challenges-concerning incorporating practice in teacher education. These findings suggest that some ways of linking to practice in teacher education seem to be established, while others are still evolving.
\end{abstract}

Keywords: teacher education, practice, coursework, comparative research

\section{Delvis etablert, delvis i utvikling: Funn fra en internasjonal studie om koblinger til praksis i lærerutdanningen}

\section{Sammendrag}

Lcrerutdannere og politikere over hele verden etterlyser en mer praksisbasert lcererutdanning med tydelige koblinger til praksis. Likevel vet vi lite om hvordan slike koblinger ser ut i ulike lererutdanningsprogram internasjonalt. I denne artikkelen undersøker vi i hvilken grad ulike læererutdanningsprogram tilbyr studentene praksisbaserte lceringsmuligheter. Studien bygger på survey data ( $n=$ 
486 lcererstudenter) fra fem lcererutdanningsprogram i Finland, Norge, California, Chile og Cuba, og observasjonsdata fra fagdidaktikkurs $(n=104$ timer) $i$ seks program i Finland, Norge og California. Ved hjelp av et analytisk rammeverk som operasjonaliserer konseptet 'praksisbaserte leringsmuligheter', viser denne artikkelen til suksesser - og utfordringer - med a innlemme praksis $i$ lcererutdanningen. Funnene indikerer at det finnes etablerte måter å koble til praksis på i lcererutdanningen, mens andre fremdeles er i utvikling.

Nøkkelord: læererutdanning, praksis, undervisning på campus, komparativt design

\section{Introduction}

Around the world, teacher education has been criticized for being fragmented and disconnected from practice (Darling-Hammond et al., 2017; Janssen, Westbroek, \& Doyle, 2014; Moon, 2016; Munthe \& Rogne, 2016; National Council for Accreditation of Teacher Education [NCATE], 2010; Niemi, 2016; Zeichner, 2012). A US Blue Ribbon Panel maintained that the challenges of preparing teachers for 21st-century classrooms demand that teacher education (TE) be "turned upside down" such that practice becomes the base for the work of learning to teach (NCATE, 2010, p. ii). A cross-case analysis of TE cases across countries including Australia, Chile, China, India, South Africa, and Uganda revealed that university-based TE has increased the status of TE, but led to greater separation from practice (Moon, 2016). Worldwide, policymakers and teacher educators are thus paying increasing attention to how teacher candidates learn to enact practice and to ground TE more deeply in the work of teachers' classroom practice. For instance, in Australia and the United Kingdom (UK), pre-service TE has established extensive collaboration between university faculty and schools to address the theory-practice gap (Taylor, 2016). In South Africa, concerns have been raised that TE faculty should reclaim their relationship with schools from temporary or adjunct staff (Eloff, 2016). Looking across these cases, Moon (2016) concluded that TE must embrace teaching practice to enhance its role in teacher preparation. Even in "high-performing" jurisdictions, as determined by student outcomes on tests such as PISA and TIMSS, countries are shifting attention to practice in TE. A study of teaching policy across three continents and five countries revealed that teacher preparation universities are continually engaged in improving their own practices. A major aspect of this self-improvement in recent years has been to extend the duration and rethink the design of clinical experiences to make them more tightly connected to coursework and program goals (Darling-Hammond et al., 2017, p. 22). For example, studies have shown that the explicit focus on research in Finnish TE may undermine practical and classroom-related skills (Groom \& Maunonen- 
Eskelinen, 2006; Säntti, Rantala, Salminen, \& Hansen, 2014). Säntti et al. (2014) demonstrated that the amount of practice and tutoring in Finnish TE has decreased from 1982 to 2006, being replaced by more self-studies (e.g., independent reading and assignments). They argued that this approach makes it more difficult for teacher candidates to integrate theory and practice. Similarly, Groom and Maunonen-Eskelinen (2006) reported less focus on teaching skills in Finnish teacher candidates' portfolios as compared to their UK peers.

Growing evidence from the United States (US) and the Netherlands has suggested that efforts to tie preparation to practice may significantly impact pupils’ learning (Boyd, Grossman, Lankford, Loeb, \& Wyckoff, 2009; Brouwer \& Korthagen, 2005; Darling-Hammond, Chung, \& Frelow, 2002). Furthermore, research has indicated that teacher preparation grounded in practice can increase teacher retention (Feiman-Nemser, Tamir, \& Hammerness, 2014) and enhance candidates' practical competence in the classroom (Brouwer \& Korthagen, 2005; Darling-Hammond et al., 2002).

Globally, teacher educators have worked to make TE more practice-based (see Forzani, 2014, for a history of these efforts in the US). Teacher educators and policymakers have strengthened connections to practice by creating deeper relationships to schools, requiring candidates to spend more time at school sites, working more closely with cooperating teachers, and creating lab or training schools. In Finland, university-initiated teacher training schools that offer candidates safe, structured environments to practice teaching, have been a part of TE for almost a century (Paksuniemi, 2009; Uusiautti \& Määttä, 2013). Recently, Norway has worked to establish "University-schools” (Lund \& Eriksen, 2016). Further, new national guidelines for a five-year integrated TE in Norway in 2013 increased the amount of practice (e.g., field placement) from 60 to 100 days (National Regulation for Teacher Education (levels 8-13), 2013). Cuban teacher education also has a strong tradition of working closely with their collaborating schools (Carnoy, 2007), including gradually increasing responsebilities for their teacher candidates during field placement periods. In the US, "professional development schools", "lab schools", or "university schools" (Holmes Group, 1995) are intended to forge greater connections to schools and stronger links with mentors and administrators. Recently, teacher residency programs have tried to ground TE more closely in practice (Berry, Loughran, \& van Driel, 2008; Darling-Hammond et al., 2017; Hammerness, Williamson, \& Kosnick, 2016; Orchard \& Ellis, 2014). These efforts focus upon the structural features connecting theory with practice, yet they also reinforce an assumption that learning about practice, and learning to teach in practice, can happen only in school placements.

In our study, we build upon a conceptualization of learning to teach in practice that expands beyond learning on site in school placements (Ball \& Cohen, 1999; Ball \& Forzani, 2009; Grossman, Hammerness, \& McDonald, 2009; Grossman \& McDonald, 2008; Orchard \& Ellis, 2014). From this 
perspective, coursework and university-based experiences are critical arenas for linking to practice. The growing body of scholarship investigating how to allow teacher candidates to enact practice in coursework is representative of this conception. Yet, few research studies have examined the degree to which coursework (i.e., learning experiences and assignments in university-based courses) is grounded in practice (Cochran-Smith et al., 2016). Furthermore, we know little about the extent to which teacher candidates in programs in different country contexts have opportunities to learn to enact practice in TE coursework on campus, how contexts might vary, and how different program designs comprise learning opportunities and experiences. What kind of attention to teaching practice do we see in the coursework in programs internationally? Are there different emphases or approaches? Do teacher candidates encounter certain kinds of connections more often in some settings than in others? Are there patterns across Nordic or American programs?

Building upon calls for more international, comparative research in TE (Blömeke \& Paine, 2008; LeTendre \& Wiseman, 2015; Zeichner \& Conklin, 2005), this article analyzes linkages to practice in TE coursework in international settings. We have tried to systematically investigate the nature of TE experiences and coursework and their relationship to practice, drawing on observation data, teacher candidates' survey data, and analyses of program data. In this paper, we examine: In what ways do methods courses provide opportunities to enact and test out different classroom practices? What kind of attention to teaching practice do we see in programs internationally? Are there any typical patterns and connections that teacher candidates encounter more often than others?

\section{Theoretical framework}

In our international study, the Coherence and Assignment Study in Teacher Education (CATE), we have drawn upon opportunities that are grounded in practice as our conceptual framework for studying a sample of TE programs across five countries. We used the "opportunities to learn” concept to investigate learning experiences in courses (Floden, 2002; see also Carroll, 1963). For this research, we developed a set of empirically based dimensions to identify candidates' opportunities to link to practice in the programs under investigation. We used these dimensions to identify the degree to which these features were at work in the studied programs and to tease apart indicators of opportunities to link to and enact practice that need more elaboration. For instance, how could we determine if a program offers opportunities to link to and enact teaching? What might indicate that a program offers opportunities to learn that are connected to the work of real classroom teaching? We also sought to better understand the variation across the programs by asking: What might those 
learning opportunities look like, and how are they implemented in such varied settings?

\section{Indicators of enactment}

To identify the opportunities for enacting practice across these programs, we developed a set of indicators to determine whether a program attempted to tie candidates' opportunities to learn to secondary teaching practices and to pupils' learning. What would it look like for programs to directly link to classroom practice, to provide opportunities to enact teaching practices (e.g., organizing groupwork, orchestrating whole-class discussion, giving feedback on pupils' work), and to ground learning in the real materials of teaching (e.g., texts, resources, pupils' work, real-world examples of teaching using national or local curriculum)?

In identifying indicators of practice-centered coursework, we drew upon research investigating ways to help new teachers learn to decompose and enact classroom practices ("high leverage" or "core practices" in TE; e.g., Ball \& Forzani, 2009; Grossman et al., 2009; McDonald, Kazemi, \& Kavanagh, 2013), as well as research on aspects of learning to teach such as lesson planning (Kunzman, 2002). We also drew from research on using artifacts and representations of teaching and pupil learning, as suggested by Ball and Cohen (1999) for establishing a pedagogy of teacher education that is grounded in practice (see also Boyd et al., 2009; Windschitl, Thompson, Braaten, \& Stroupe, 2012 on this issue).

Due to the exploratory nature of our study and questions about the transferability of indicators to different contexts, we sought to capture potentially common or shared representations of practice across international settings. For that reason, we chose not to look for finer-grained teaching practices such as organizing a whole-class discussion (Edwards-Groves \& Hoare, 2012; Grossman, Loeb, Cohen, \& Wyckoff, 2013) or conducting behavioral management (Pianta \& Hamre, 2009) because they might be more specific to the context. For an initial comparative exploratory study, we decided to focus on features most likely to be shared across settings and to resonate across different programs. A pilot study (Klette \& Hammerness, 2012) using the US (California) and Norway (Oslo) programs confirmed these assumptions.

Our framework considers teaching practice to be complex, situated, and instantaneous, but something that can be developed with sufficient scaffolding and support. Eight dimensions constitute our conceptual and analytical framework. These dimensions, which are a starting point for examining how TE coursework is grounded in practice, are outlined below and summarized in Table 1. 
Table 1: Dimensions of Opportunities to Enact Practice (OEP) in teacher education

\begin{tabular}{|c|c|}
\hline Opportunities to ... & Description of dimension \\
\hline $\begin{array}{l}\text { 1. plan for teaching } \\
\text { and teacher role(s) }\end{array}$ & $\begin{array}{l}\text { The extent to which candidates have opportunities to plan lessons or units, or } \\
\text { to develop instructional materials. }\end{array}$ \\
\hline $\begin{array}{l}\text { 2. practice and } \\
\text { rehearse teacher } \\
\text { role(s) }\end{array}$ & $\begin{array}{l}\text { The extent to which candidates have opportunities to practice, rehearse, or } \\
\text { approximate elements of practice. This includes practice leading a whole-class } \\
\text { or small-group discussion, roleplaying a discussion with a pupil, rehearsing a } \\
\text { lesson introduction, or participating in a fishbowl discussion taking the part of } \\
\text { a pupil or a teacher. }\end{array}$ \\
\hline $\begin{array}{l}\text { 3. analyze pupils’ } \\
\text { learning }\end{array}$ & $\begin{array}{l}\text { The extent to which candidates have opportunities to practice analyzing pupil } \\
\text { learning; to examine or analyze pupil work; to work with pupils and analyze } \\
\text { their skills, abilities, or needs; or to look at classroom transcripts or videos and } \\
\text { analyze pupil learning. }\end{array}$ \\
\hline $\begin{array}{l}\text { 4. include teaching } \\
\text { materials, artifacts, } \\
\text { and resources }\end{array}$ & $\begin{array}{l}\text { The extent to which candidates have opportunities to use, discuss, or analyze } \\
\text { artifacts or resources from real classrooms and teaching, including videos of } \\
\text { teachers, cases about teaching and teachers, samples of real pupil work, and } \\
\text { transcripts of classroom talk. }\end{array}$ \\
\hline $\begin{array}{l}\text { 5. talk about field } \\
\text { placement }\end{array}$ & $\begin{array}{l}\text { The extent to which candidates have opportunities to discuss or relate what } \\
\text { they are discussing or doing in class to their own fieldwork or student-teaching } \\
\text { (e.g., bring in their own pupils' work). }\end{array}$ \\
\hline $\begin{array}{l}\text { 6. take pupils’ } \\
\text { perspective }\end{array}$ & $\begin{array}{l}\text { The extent to which candidates have opportunities to do work that their own } \\
\text { pupils will or might do (e.g., read texts or solve problems) or to take the pupils' } \\
\text { perspective (in terms of learning styles, adolescent perspectives and concerns, } \\
\text { pupils' needs and strengths). }\end{array}$ \\
\hline $\begin{array}{l}\text { 7. see models of } \\
\text { teaching }\end{array}$ & $\begin{array}{l}\text { The extent to which candidates have opportunities to see teacher educators } \\
\text { modeling the practices discussed in class (e.g., a good lecture for K-12 pupils, } \\
\text { group work, or giving good feedback). }\end{array}$ \\
\hline $\begin{array}{l}\text { 8. see connection } \\
\text { to national or state } \\
\text { curriculum }\end{array}$ & $\begin{array}{l}\text { The extent to which candidates have opportunities to read, review, critique, or } \\
\text { analyze materials specific to the national, state, or local context (e.g., read or } \\
\text { analyze national, state, or local curriculum or local regulations for teacher } \\
\text { evaluation or standards). }\end{array}$ \\
\hline
\end{tabular}

Plan for teaching and teacher role(s). Scholarship on TE has revealed that planning is a key strategy for learning to teach and connecting to practice (Grossman et al., 2009; Kunzman, 2002; Windschitl et al., 2012). Windschitl et al. (2012) identified planning as a core practice of teaching and developed a tool to guide their candidates' planning skills, focusing on constructing the big ideas of science teaching. Kunzman (2002) found that teacher preparation helped teacher candidates develop their planning capacities and design their instruction based on their visions of good teaching. Examining preparation programs, Grossman et al. (2009) found that teacher candidates had fewer opportunities to enact practice (OEP; e.g., lesson and unit planning) than novices in other professions.

Practice and rehearse teacher role(s). Scholars have argued that, to be more centered in practice, courses must allow candidates to practice and rehearse teaching, not just read about teaching (Ball \& Forzani, 2009; Grossman et al., 2009; Kennedy, 1999). Potential practices include responding to pupils' mathematical ideas (Lampert et al., 2013), engaging pupils in investigations (Janssen et al., 2014; Kloser, 2014), reading aloud (Reid, 2011), and modeling historical thinking (Fogo, 2014) or mathematical procedures (Hiebert \& Grouws, 2007). 
Studies have identified these opportunities as those most neglected in TE, so we wondered whether the programs we examined provided such opportunities.

Analyze pupils' learning. Some work on grounding in practice has focused on providing opportunities for new teachers to analyze pupils' work for trends or patterns (Ball \& Cohen, 1999; Boyd et al., 2009; Windschitl et al., 2012). Ball and Cohen (1999) noted that "samples of student work could be used to inquire into what students have learned, and whether it was what the teacher intended" (p. 14). Hiebert, Morris, Berk, and Jansen (2007) argued that knowledge about pupils' learning could inform the teacher candidates about the effects of their instructional practices.

Include teaching materials, artifacts, and resources. Scholars have argued that teachers need opportunities to study tasks and teaching materials relevant for prospective classroom teaching (e.g., lesson plans, learning materials, assignments, textbooks). Examining these "records of practice" makes teaching practice "studyable" and helps new teachers see different versions of teaching and learning (Ghousseini \& Sleep, 2011; Martínez, Borko, \& Stecher, 2012).

Talk about field placement. Providing opportunities to talk about field placement and connect theories of teaching and learning with classroom experience decisively links coursework and practice. However, teacher candidates need structure and support when reflecting on their experiences (DarlingHammond, Holtzman, Gatlin, \& Heilig, 2005). The focus on research-based TE in Finland (Niemi, 2016), Norway, and Ireland (Conway \& Munthe, 2015) has emphasized that candidates should develop an inquiry stance toward their own teaching and make autonomous, professional choices based upon informed reflection. Similarly, reflection on practice has been highlighted in the US (Valli, 1997) and the Netherlands (Tigchelaar \& Korthagen, 2004).

Take pupils' perspective. In New Zealand, teacher educators have described opportunities for candidates to play the role of pupils within a problem-solving approach to teaching mathematics (Bailey \& Taylor, 2015). Bailey and Taylor (2015) argued that this experience helped the candidates envision how this "ambitious teaching" (p. 121) could be enacted in the future. In the Nordic countries, taking the pupils' perspective is also evident in the "seminar tradition" (see Rasmussen, 2008) in which teacher candidates are expected to prepare to become teachers by doing the same tasks and assignments that their prospective pupils will do (Kvalbein, 2003).

See models of teaching. Further, scholars have argued that teacher educators should model practice to allow candidates to witness and understand complex, ambitious teaching practices (Bailey \& Taylor, 2015; Kvalbein, 2003; McDonald et al., 2014). McDonald et al. (2014) underscored the importance of teacher educators modeling teaching practices before the candidates practice them in "mediated field placements" (p. 501).

See connection to national or state curriculum. In the Nordic countries, national curricula represent a tradition of linking abstract principles with class- 
room teaching (Carlgren \& Klette, 2008; Niemi, 2016). The New York City Pathways study identified chances to examine state standards or disciplinary standards (e.g., National Council of Teachers of Mathematics standards) and local curriculum (Boyd et al., 2009) as influential practice-based opportunities.

Table 1 summarizes the overall conceptual framework in the CATE study. This framework was used to analyze ways the different programs might connect theory and practice in the observation data, and it was used to develop the survey instrument, which we also report on in this paper.

\section{Methods}

\section{Participating programs}

We designed this exploratory study as a multiple-case study, sampling cases to provide information about how coursework is grounded in practice with sufficeent diversity and opportunity to learn about complexity concerning this phenomenon across contexts (Stake, 2006, p. 23). We used a comparative design focusing on eight programs in five countries: Cuba, Chile, Finland, Norway, and the US. ${ }^{1}$ We selected institutions that prepared teachers for grades 8-13, due to the increasing attention on secondary student achievement (e.g., on tests such as TIMSS and PISA), providing a broader context for our findings. Participating programs were situated at the University of Helsinki and Åbo Akademi University in Finland; the University of Oslo and Norwegian University of Science and Technology (NTNU) in Norway; Stanford University and the University of California, Santa Barbara (UCSB), in California, US; the Instituto Superior Pedagógico Enrique José Varona in Havana, Cuba; and Pontificia Universidad Católica de Chile (PUC), in Santiago. ${ }^{2}$

Purposive sampling is preferable for multiple-case studies over sampling the most typical cases (Stake, 2006). We chose contexts that offered variation in ways of grounding teacher preparation in practice, while being similar enough for comparison. All programs represented contexts that have redesigned TE by strengthening the link to practice. For instance, Finland has long emphasized teacher preparation and a skilled teaching force including teacher training at the master's degree level in all subject areas and grade levels (Organization for Economic Co-operation and Development [OECD], 2014; Sahlberg, 2011). Both Helsinki and Åbo Akademi University have supported local teacher training schools that serve as sites for fieldwork and student teaching. Stanford has redesigned their teacher training program around a well-articulated vision of good teaching, including substantial efforts to integrate courses with field placement and opportunities for candidates to rehearse teaching (Hammerness, 2006). The University of Oslo, with a less developed national tradition for teacher preparation research (Munthe \& Haug, 2009), has been undergoing substantial reform that reflects a growing nationwide TE reform. Norway has invested 
substantial resources and efforts in teacher education (Munthe, Malmo, \& Rogne, 2011; Norwegian Agency for Quality Assurance in Education [NOKUT], 2006); beginning in 2017, all Norwegian K-12 teachers must hold a master's degree (Norwegian Government, 2014). In 2007, Chile initiated national policy changes to improve TE including required accreditation for all programs, a new exit exam, and required standards for all new teachers. Since 2010, the program at Santiago has been deepening pedagogies of practice. Cuban TE has contributed to an "outstanding" educational system, enabling schools to perform like those in OECD countries, despite Cuba's status as a developing nation (Gasperini, 2000).

Almost all programs were one-year programs candidates attended following a bachelor's or master's degree. Some programs (i.e., the Finnish programs and NTNU) had a flexible five-year or one-year design (see Table 2).

Table 2: Background information per program

\begin{tabular}{|c|c|c|c|c|c|c|c|c|c|}
\hline \multirow[t]{2}{*}{ Program } & \multicolumn{2}{|c|}{$\begin{array}{l}\text { Length } \\
\text { of pro- } \\
\text { gram }\end{array}$} & \multicolumn{2}{|c|}{$\begin{array}{l}\text { Organi- } \\
\text { zation of } \\
\text { fieldwork }\end{array}$} & \multirow{2}{*}{$\begin{array}{l}\text { Amount } \\
\text { of field- } \\
\text { work in } \\
\text { hours }\end{array}$} & \multirow{2}{*}{$\begin{array}{l}\text { Acceptance } \\
\text { rates into the } \\
\text { programs, } \\
\text { in } \%\end{array}$} & \multirow[t]{2}{*}{$\begin{array}{l}\text { No. of } \\
\text { candidates }\end{array}$} & \multirow[t]{2}{*}{$\begin{array}{l}\text { Participants } \\
\text { in survey } \\
\text { study }\end{array}$} & \multirow[t]{2}{*}{$\begin{array}{l}\% \text { male } \\
\text { partici- } \\
\text { pants }\end{array}$} \\
\hline & 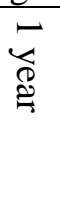 & 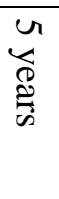 & 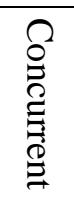 & 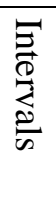 & & & & & \\
\hline Helsinki & & $\mathrm{x}$ & & $\mathrm{x}$ & 540 & $10-40^{\mathrm{a}}$ & 410 & 75 & 32 \\
\hline Åbo & & $\mathrm{x}$ & & $\mathrm{X}$ & 432 & $89^{b}$ & 40 & $-^{\mathrm{e}}$ & $-^{\mathrm{e}}$ \\
\hline Oslo & $\mathrm{x}$ & & & $\mathrm{x}$ & 480 & 21 & 160 & 122 & 42 \\
\hline NTNU & & $\mathrm{x}$ & & $\mathrm{x}$ & 520 & 44 & 220 & $-^{\mathrm{e}}$ & $-^{\mathrm{e}}$ \\
\hline Stanford & $\mathrm{x}$ & & $\mathrm{x}$ & & 780 & $-^{\mathrm{c}}$ & 72 & 72 & 35 \\
\hline UCSB & $\mathrm{x}$ & & $\mathrm{X}$ & & 1000 & 67 & 29 & $-^{\mathrm{e}}$ & $-^{\mathrm{e}}$ \\
\hline PUC & $\mathrm{x}$ & & $\mathrm{x}$ & & 360 & 48 & 96 & 78 & 31 \\
\hline Varona & & $\mathrm{x}$ & $\mathrm{x}$ & & 1280 & $-^{\mathrm{c}}$ & $19^{\mathrm{d}}$ & $139^{f}$ & 26 \\
\hline
\end{tabular}

${ }^{a}$ Depending on subject. ${ }^{b}$ The acceptance rate seems high because the Finnish education system has three types of teachers: subject teachers, class teachers, and special education teachers. Our sample is from a program for subject teachers, which has a higher acceptance rate because these candidates have already completed one university acceptance process for their major studies. In comparison, the acceptance rates at Åbo in 2012 were only 22\% for class and 13\% for special education teacher candidates. ${ }^{\mathrm{c}}$ These data were not obtained. ${ }^{\mathrm{d}}$ This program educates math teachers only. ${ }^{\mathrm{e}}$ Data not obtained (e.g., due to too small sample size or reversed items not reverse rated). ${ }^{\mathrm{f}}$ Including candidates from programs providing other subject matter preparation than mathematics.

Also, the acceptance rates were low at all programs, except for UCSB. The program size varied (see Table 2) from Helsinki as the largest and Santa Barbara and Åbo as the smallest.

\section{Data sources, data collection, and analysis}

Drawing upon classroom observations, related artifacts, and surveys of teacher candidates, this study aimed to examine the degree to which the programs provide opportunities to link to and enact practice during coursework. In 
understanding program variation, we operationalized these indicators in our instruments (e.g., surveys, rubrics) to identify their presence or absence in the programs.

The third author collected data at two sites, while four trained research assistants collected data at the other sites. The assistants spoke the language of instruction, and the instruments used were developed within the CATE study (see Hammerness \& Klette, 2015, for an overview of the data collection). Below, we briefly describe the data sources and collection instruments.

\section{Surveys}

We developed a survey to investigate candidates' OEP, drawing on the conceptual framework and eight dimensions outlined above. The survey includes items on issues of coherence across the program elements; however, teacher candidates' perceptions on program coherence are reported in separate articles (see Canrinus, Bergem, Klette, \& Hammerness, 2015, 2017). In this article, we report on the survey items tapping the teacher candidates' opportunities to enact practice during campus coursework (11 items in total, see Figure 1). To ensure the instrument was linked to high-quality analytical tools used in relevant educational studies, the survey builds on the instrument used in the New York City Pathways Study (Boyd et al., 2006). Boyd et al. designed their study to explore the characteristics of TE programs in the New York region. Our survey asked teacher candidates to indicate on a four-point scale $(1=$ none; $4=$ extensive opportunity) the extent to which they had the opportunity to do what was described in each item. To ensure that items were understood and were valid and reliable after translation, we performed cognitive interviews with some candidates at Helsinki, Stanford, and Oslo. Analyses revealed that candidates understood the terms and did not reveal any problematic items.

Survey data were collected from 486 teacher candidates across the five programs (see Table 2). Participation in this study was strictly voluntary. As we used a paper-and-pencil survey distributed at mandatory courses, response rates for four of the five programs were close to $100 \%$. The only exception to this was Helsinki $(23 \%)^{3}$, which lacked obligatory classes and offered flexible scheduling. All students present in class when we distributed the survey returned a completed survey. Even though the overall response rate at Helsinki was low, this sample appears to be representative as respondents' ages and subjects were similar to the population. Across all five programs, the participants consisted of $33 \%$ males, similar to the average gender distribution in the teaching population in OECD countries (OECD, 2013).

\section{Analyses of survey data}

To investigate similarities and differences between the programs, we used analysis of variance (ANOVA) at the scale level and multivariate ANOVA at the item level. We checked for homogeneity of variance using Levene's test. 
This outcome showed that variances were unequally distributed across the programs. Therefore, we used the Welch F-test to compare all programs and Games Howell to explore similarities and differences between programs (Tomarken \& Serlin, 1986).

\section{Observations}

Observations occurred over a three-week period at each of the six initially participating TE programs. This resulted in approximately eight hours of teaching in each course at each program, a total of 104 hours of observation. While three weeks represents a limited period for candidates to make connections to practice in their methods courses, observational studies from $\mathrm{K}-12$ classrooms have suggested that four consecutive lessons per classroom provide sufficient information for an overview of teaching quality (Ball \& Hill, 2009; Klette, 2009). As such, we estimated that three weeks in a TE classroom would be sufficient. Altogether, this study covered 18 weeks of observation, offering valuable insight into the teaching practices of these TE programs.

The authors systematically trained all assistants to take detailed field notes, including spoken dialogue and exact quotations. The observations were typed as real-time field notes. On average, we had 10-15 pages of observation notes for each class. To support our analysis, our data included artifacts like typed or handwritten assignments, PowerPoint slides, and candidates' work in class. The written notes and supportive artifacts constituted the data for our analysis.

\section{Analysis of observation data}

We coded the candidates' OEP based on the eight dimensions in our analytical framework using the software HyperResearch 3.5.2. We wanted to capture the extent of these opportunities (e.g., quality and time), so we developed a coding book that operationalizes each dimension on a 1-4 scale. ${ }^{4}$ We assigned each lesson a score for each dimension. Reported scores (one for each dimension) were the averages of the scores of all lessons we observed during the three weeks in each TE program (see Figure 1). We double-coded $8.7 \%$ of our data to calibrate the scoring. The strength of agreement was good with Kappa $=0.66$ (Fleiss, Levin, \& Paik, 2003). ${ }^{5}$ After inter-rater reliability was established, the first author coded all lessons and picked excerpts to illustrate the characteristics of a higher score of the dimensions.

\section{Findings}

\section{Surveys}

Analyses of survey data suggest considerable similarities across the programs. Looking at the candidates' opportunities to enact certain practices in our framework, relative to other practices, all programs' candidates reported they had 
most extensive opportunities to do the following: plan for teaching (1A), examine national/state/local curriculum (1F), examine actual teaching materials (1E), and discuss experiences from field experiences (1I); see Figure 1.

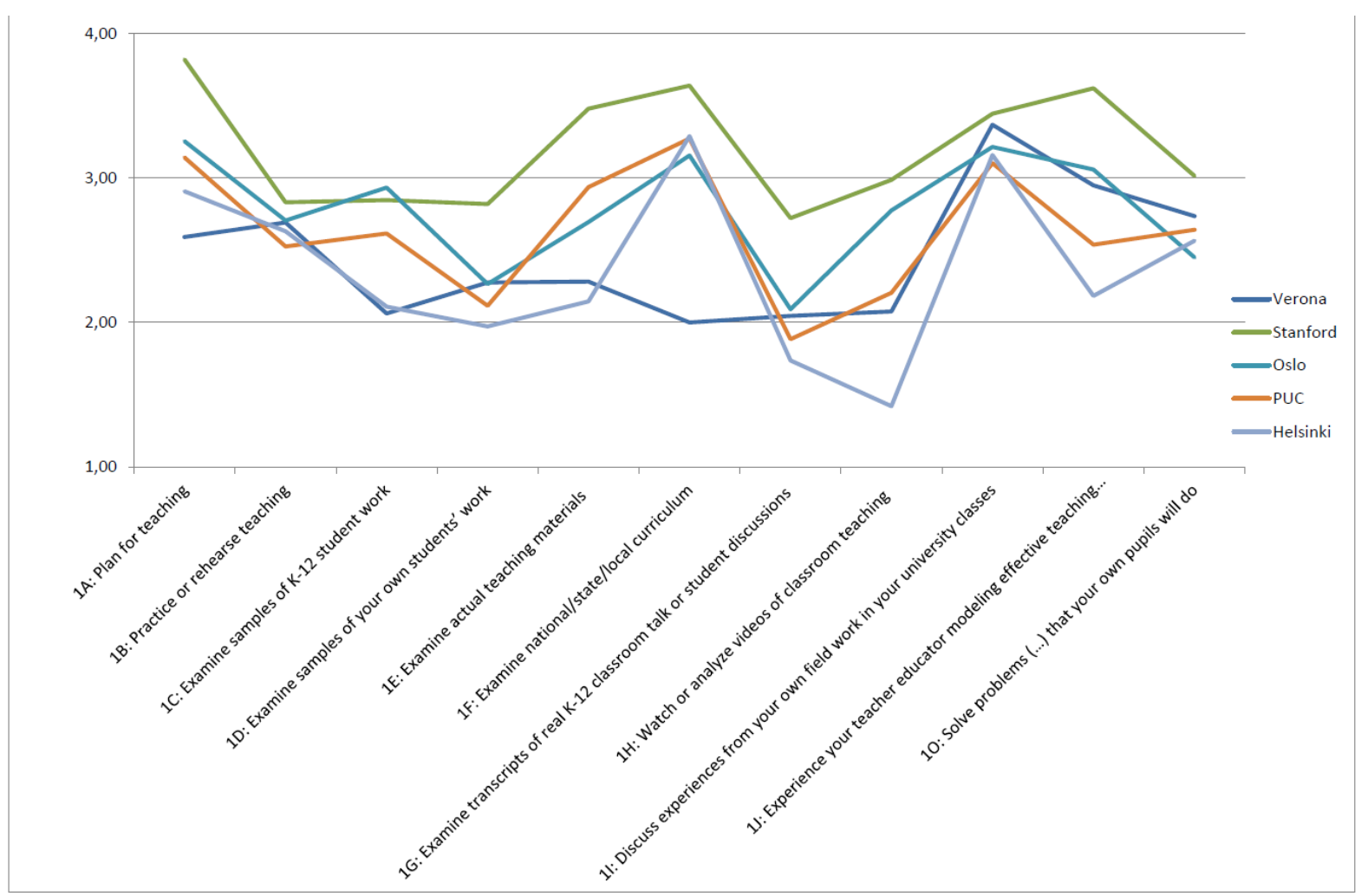

Figure 1. Mean score per item per program

Similarly, candidates across all programs reported having the fewest opportunities to examine samples of $\mathrm{K}-12$ students' work (1C), examine transcripts of $\mathrm{K}-12$ classroom talk $(1 \mathrm{G})$, and watch or analyze videos of classrooms teaching $(1 \mathrm{H})$. The findings reveal a similar pattern of OEP across programs.

\section{Observations}

Our analysis revealed that candidates had extensive OEP by the inclusion of teaching materials, artifacts, and resources (dimension 4 [D4]) and by taking the pupils' perspective (D6). They had some opportunities to talk about field placement (D5), plan for teaching and teacher role(s) (D1), and see the connection to national, state, or local curriculum (D8). The teacher candidates had few opportunities to practice or rehearse teacher role(s) (D2), analyze pupils' learning (D3), or see models of teaching (D7). Figure 2 summarizes these findings across programs. 


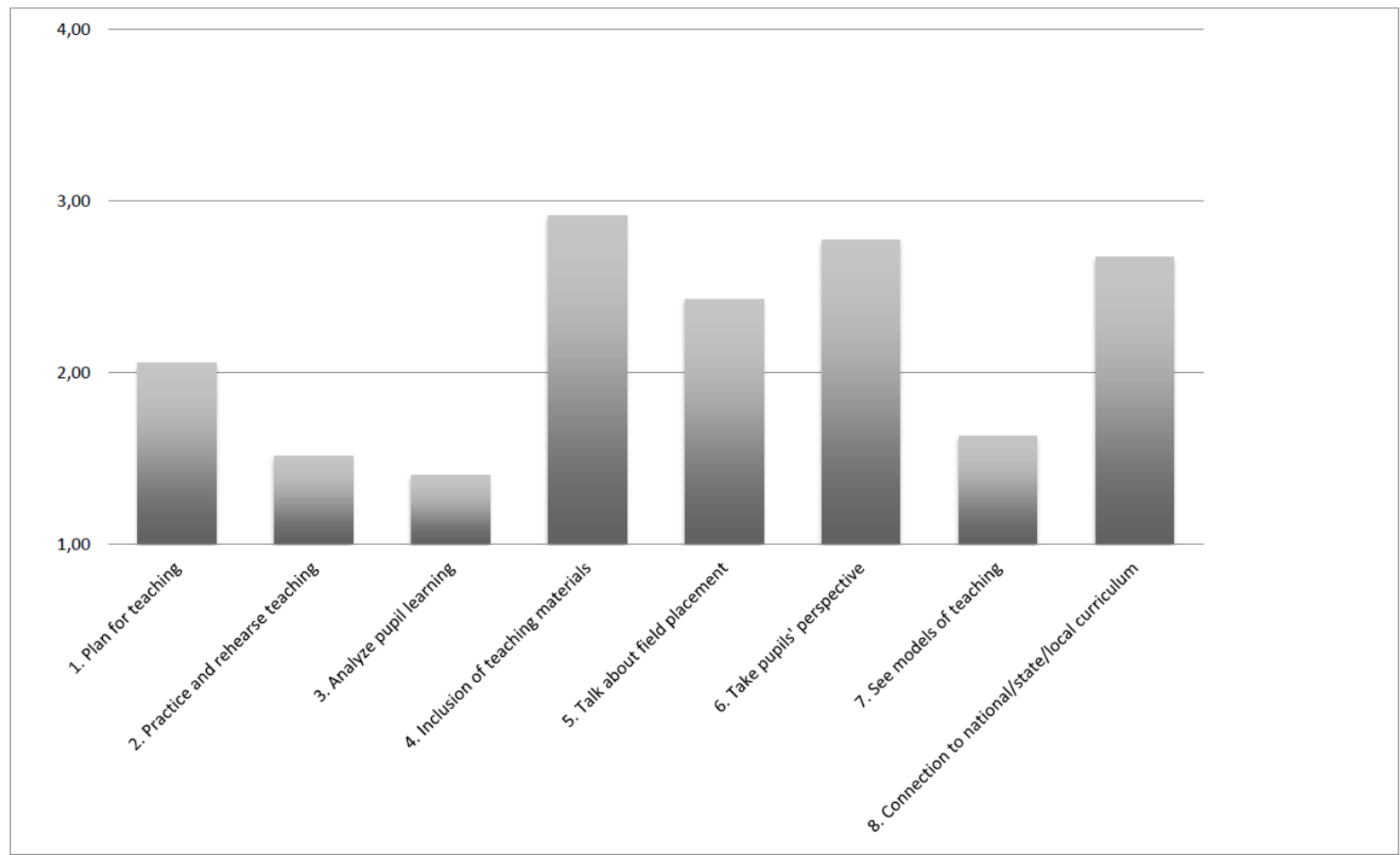

Figure 2. The extensiveness of OEP across all programs, expressed as the mean of scores for each dimension across all observations

As displayed in Figure 2, we found a tendency across all programs for candidates to have fewer opportunities to rehearse teaching, analyze pupils' learning, and see models of teaching practices than include teaching materials and take the pupils' perspective (e.g., solve tasks and assignments their pupils might be given). As such, the observation data corroborates the pattern found in the survey data (Figure 1).

\section{Discussion}

Our findings indicate that the dimensions we explored resonate across programs and with teacher candidates. Cognitive interviews with some candidates demonstrate that the survey 'made sense' even in very different contexts, and they understood what we were asking them. Despite the challenges of cross-case, comparative work (cf. Blömeke \& Paine, 2008) and challenges in translating our surveys, our findings suggest comparable data that reveal linkages to practice in these programs and enabled us to look across programs. Overall, our instruments give a glimpse into the 'black box' of how TE coursework provides opportunities to link to practice. Furthermore, our survey and observation findings illustrate similar themes and patterns in what we have termed 'established' and 'evolving' ways of linking to practice in different program and country contexts.

Across all programs, we see evidence of opportunities to link to practice. For instance, our survey data and observation data reveal that candidates in all 
programs had considerable opportunities to work with real artifacts (e.g., textbooks, syllabi, course materials). We also find that candidates had considerable opportunities to connect their work to the national curricula across programs. Given the importance of designing curricula that link to opportunities for teacher candidates to learn, this is an encouraging finding.

Lesson planning has been a stable and consistent facet of teacher practice in TE programs (Kunzman, 2002). While the findings across our data sources differ slightly, we find that candidates in all programs had several opportunities to plan for teaching. Given that this is a critical feature of teaching, it seems appropriate that candidates had considerable opportunities in this area. While we see fewer planning opportunities in our observation data, this may be due to the timing of our observations in the methods courses, as some of the programs had their fieldwork organized in intervals, and might not have emphasized planning in periods when the candidates were not about to enter their fieldwork. In the observation data, we also see considerable opportunities for candidates to take the pupils' perspective, which is a critical part of planning and understanding how pupils may make sense of tasks and materials.

We also identify considerable opportunities to talk about field placements. Methods courses and the coursework on campus represent an important site for candidates to reflect upon and deconstruct their experiences in schools. We would assume that programs make these connections possible and frequent for candidates in coursework at the university. Yet, we acknowledge that this kind of talk may not always be of high quality and may not get candidates closer to enacting practice.

Overall, our data sources reveal somewhat fewer opportunities to rehearse or roleplay teaching practices. Our data suggest some opportunities in this area and perhaps more than we expected given the rarity of these occurrences in US teacher education (Grossman et al., 2009). Related to these OEP, teacher educators have acknowledged that the shift toward practice-based TE requires considerable changes for teacher educators themselves. Asking candidates to enact, simulate, and rehearse requires teacher educators to shift their practices away from leading discussions and reflective conversations toward modeling and coaching such practices (Grossman et al., 2009; Stroupe \& Windschitl, in press). Given the relative newness of the work to involve teacher candidates in enacting practices, we are somewhat surprised to find that candidates reported teacher educators modeling practices, though this finding differed across data sources.

Our candidates reported fewer opportunities to look at samples of pupils' work, to analyze videos from real classrooms, and to analyze examples of work by real classroom teachers. These resources seem to be used far less frequently by teacher educators, perhaps because of issues with access, permission, or lack of high-quality examples. Indeed, candidates in these programs reported fewer opportunities to discuss, consider, and analyze pupil learning, yet many educators would agree that analyzing pupils' work and strategizing how to use the 
findings to inform instruction is central to the work of teaching. Increasingly, teacher educators argue that pupils' learning should be at the center of teacher learning and education (Windschitl et al., 2012). Indeed, recent research has found that mentor-teacher candidate teams learn even more deeply when pupils' work is at the center (Thompson, Windschitl, \& Braaten, 2013). Our consistent finding about the scarcity of such opportunities points to a generative and important area for attention and improvement.

\section{Implications}

This study's findings point to some key implications for TE in methods and research as well as in program design and pedagogy. This cross-case, comparative study provides initial data suggesting that, on some level, we can begin to look at issues of linkages to practice and find patterns across programs. While we recognize the considerable contextual differences, the consistent patterns we see across data sources and across programs suggest that, within TE, we can work to develop some common understandings and frameworks that allow for examination across contexts. Our initial findings also suggest that the development of instruments and measures to be used across programs, even in quite different national contexts, is a worthwhile and potentially fruitful pursuit.

Despite the differences in programs, policy contexts, and national educational contexts, our research reveal the potential for cross-case examination to offer understanding of the longstanding challenges of linking TE to teaching practice. Across these programs, we see established and evolving approaches of connecting to practice, and we see evidence of both efforts across our data sources. Opportunities to ground candidates' learning in artifacts of teaching and to learn about teaching in the context of national curriculum, for instance, seem well established in the programs we studied. While we were less certain we would see opportunities to enact teaching practice or to rehearse or simulate such practice, we find growing evidence suggesting that they are evolving and gaining ground in the programs. We also see some evolving opportunities to analyze pupil learning. It might be useful for each program to consider its current opportunities and ask if they seem appropriate or if some areas need more attention. Looking across programs not only confirms efforts to strengthen links to practice, showing some areas that reveal increasing attention, but also illuminates arenas for even deeper connections to practice that programs can now begin to pursue. 


\section{About the authors}

Kirsti Klette is a professor at the Department of Teacher Education and School Research, University of Oslo. Her research interests include research on teaching and learning, teacher quality, classroom studies and comparative teacher education. She has been the principal investigator for several international and comparative projects. She is currently the principal investigator of the CATE study along with Karen Hammerness, and is the principal investigator of a largescale classroom video study - the Linking Instruction and Student Achievement (LISA) study, both funded by the Research Council of Norway.

Institutional affiliation: Department of teacher education and school research, University of Oslo, P.O. box 1099 Blindern, 0317 Oslo

Email: kirsti.klette@ils.uio.no

Karen Hammerness is the Director of Educational Research and Evaluation at the American Museum of Natural History in New York City. Her research focuses upon the pedagogy and practice of teacher education in the US and internationally. She is particularly interested in the preparation of teachers to enact teaching practice as well as preparation for specific contexts for teaching (such as urban settings). Karen along with Kirsti Klette is a principal investigator of the CATE research study.

Institutional affiliation: American Museum of Natural History, New York City, Central Park West at 79th Street, New York, NY 10024-5192, US

Email: khammerness@amnh.org

Inga Staal Jenset is a university lecturer at the Department of Teacher Education and School Research, University of Oslo. Her research interests include pedagogy of teacher education, with a particular interest in the practice-related instructional practices of teacher education coursework. She has been involved in the CATE study (Coherence and Assignments in Teacher Education).

Institutional affiliation: Department of teacher education and school research, University of Oslo, P.O. box 1099 Blindern, 0317 Oslo

Email: i.s.jenset@ils.uio.no

\section{References}

Bailey, J., \& Taylor, M. (2015). Experiencing a mathematical problem-solving teaching approach: Opportunities to identify ambitious teaching practices. Mathematics Teacher Education and Development, 17(2), 111-124. Retrieved from http://files.eric.ed.gov/fulltext/EJ1085902.pdf

Bakeman, R., \& Quera, V. (2011). Sequential analysis and observational methods for the behavioral sciences. New York, NY: Cambridge University Press. 
Ball, D. L., \& Cohen, D. K. (1999). Developing practice, developing practitioners: Toward a practice-based theory of professional education. In G. Sykes \& L. Darling-Hammond (Eds.), Teaching as the learning profession: Handbook of policy and practice (pp. 3-32). San Francisco, CA: Jossey Bass.

Ball, D. L., \& Forzani, F. M. (2009). The work of teaching and the challenge for teacher education. Journal of Teacher Education, 60(5), 497-511. DOI: https://doi.org/10.1177/0022487109348479

Ball, D. L., \& Hill, H. C. (2009). Measuring teacher quality in practice. In D. H. Gitomer (Ed.), Measurement issues and assessment for teaching quality (pp. 80-98). Thousand Oaks, CA: Sage Publications.

Berry, A., Loughran, J., \& van Driel, J. H. (2008). Revisiting the roots of pedagogical content knowledge. International Journal of Science Education, 30(10), 1271-1279. DOI: https://doi.org/10.1080/09500690801998885

Blömeke, S., \& Paine, L. (2008). Getting the fish out of the water: Considering benefits and problems of doing research on teacher education at an international level. Teaching and Teacher Education, 24(8), 2027-2037. DOI: https://doi.org/10.1016/j.tate.2008.05.006

Boyd, D. J., Grossman, P., Lankford, H., Loeb, S., Michelli, N. M., \& Wyckoff, J. (2006). Complex by design: Investigating pathways into teaching in New York City schools. Journal of Teacher Education, 57(2), 155-166. DOI: https://doi.org/10.1177/0022487105285943

Boyd, D. J., Grossman, P. L., Lankford, H., Loeb, S., \& Wyckoff, J. (2009). Teacher preparation and student achievement. Educational Evaluation and Policy Analysis, 31(4), 416-440. DOI: https://doi.org/10.3102/0162373709353129

Brouwer, N., \& Korthagen, F. (2005). Can teacher education make a difference? American Educational Research Journal, 42(1), 153-224. DOI: https://doi.org/10.3102/00028312042001153

Canrinus, E. T., Bergem, O. K., Klette, K., \& Hammerness, K. (2015). Coherent teacher education programmes: Taking a student perspective. Journal of Curriculum Studies, 49(3), 313-333. DOI: https://doi.org/10.1080/00220272.2015.1124145

Canrinus, E. T., Bergem, O. K., Klette, K., \& Hammerness, K. (2017). Opportunities to enact practice in campus courses: Taking a student perspective. Submitted manuscript.

Carlgren, I., \& Klette, K. (2008). Reconstructions of Nordic Teachers: Reform policies and teachers' work during the 1990s. Scandinavian Journal of Educational Research, 52(2), 117-133. DOI: https://doi.org/10.1080/00313830801915754

Carnoy, M. (2007). Cuba's academic advantage: Why students in Cuba do better in school. Stanford, CA: Stanford University Press.

Carroll, J. (1963). A model for school learning. Teachers College Record, 64(8), 723-733.

Cochran-Smith, M., Villegas, A. M., Abrams, L. W., Chávez-Moreno, L. C., Mills, T., \& Stern, R. (2016). Research on teacher preparation: Charting the landscape of a sprawling field. In D. H. Gitomer \& C. A. Bell (Eds.), Handbook of research on teaching (5th ed.; pp. 439-547). Washington, DC: American Educational Research Association.

Conway, P. F., \& Munthe, E. (2015). The practice turn. Research-informed clinical teacher education in two countries. In J.-K. Smedby \& M. Stutphen (Eds.), From vocational to professional education. Educating for social welfare (pp. 146-163). London, England: Routledge.

Darling-Hammond, L., Burns, D., Campbell, C., Goodwin, L., Hammerness, K., Low, E. L., Zeichner, K. M. (2017). Empowered Educators: How high performing systems shape teaching quality around the world. San Francisco, CA: Jossey-Bass. 
Darling-Hammond, L., Chung, R., \& Frelow, F. (2002). Variation in teacher preparation: How well do different pathways prepare teachers to teach? Journal of Teacher Education, 53(4), 286-302. DOI: https://doi.org/10.1177/0022487102053004002

Darling-Hammond, L., Holtzman, D. J., Gatlin, S. J., \& Heilig, J. V. (2005). Does teacher preparation matter? Evidence about teacher certification, Teach for America, and teacher effectiveness. Education Policy Analysis Archives, 13(42), 1-51. DOI: https://doi.org/10.14507/epaa.v13n42.2005

Edwards-Groves, C. J., \& Hoare, R. L. (2012). “Talking to learn”: Focussing teacher education on dialogue as a core practice for teaching and learning. Australian Journal of Teacher Education, 37(8), 82-100. Retrieved from http://ro.ecu.edu.au/cgi/viewcontent.cgi?article=1902\&context=ajte

Eloff, I. (2016). The missions and meanders of teacher education in South-Africa. In B. Moon (Ed.), Do universities have a role in the education and training of teachers? An international analysis of policy and practice (pp. 157-230). Cambridge, UK: Cambridge University Press.

Feiman-Nemser, S., Tamir, E., \& Hammerness, K. (Eds.). (2014). Inspiring teaching. Preparing teachers to succeed in mission-driven schools. Cambridge, MA: Harvard Education Press.

Fleiss, J. L., Levin, B., \& Paik, M. C. (2003). Statistical methods for rates and proportions. Hoboken, NJ: Wiley.

Floden, R. E. (2002). The measurement of opportunity to learn. In A. C. Porter \& A. Gamoran (Eds.), Methodological advances in cross-national surveys of educational achievement (pp. 231-266). Washington, DC: National Academy Press.

Fogo, B. (2014). Core practices for teaching history: The results of a Delphi Panel survey. Theory \& Research in Social Education, 42(2), 151-196. DOI: https://doi.org/10.1080/00933104.2014.902781

Forzani, F. M. (2014). Understanding “core practices” and "practice-based” teacher education: Learning from the past. Journal of Teacher Education, 65(4), 357-368. DOI: https://doi.org/10.1177/0022487114533800

Gasperini, L. (2000). The Cuban education system: Lessons and dilemmas. Retrieved from The World Bank, Latin America and Caribbean Regional Office: http://documents.worldbank.org/curated/en/154191468749724038/pdf/multi-page.pdf

Ghousseini, H., \& Sleep, L. (2011). Making practice studyable. ZDM, 43(1), 147-160. DOI: https://doi.org/10.1007/s11858-010-0280-7

Groom, B., \& Maunonen-Eskelinen, I. (2006). The use of portfolios to develop reflective practice in teacher training: A comparative and collaborative approach between two teacher training providers in the UK and Finland. Teaching in Higher Education, 11(3), 291-300. DOI: https://doi.org/10.1080/13562510600680632

Grossman, P., Compton, C., Igra, D., Ronfeldt, M., Shahan, E., \& Williamson, P. W. (2009). Teaching practice: A cross-professional perspective. Teachers College Record, 111(9), 2055-2100. Retrieved from http://tedd.org/wp-content/uploads/2014/03/Grossman-et-alTeaching-Practice-A-Cross-Professional-Perspective-copy.pdf

Grossman, P., Hammerness, K., \& McDonald, M. (2009). Redefining teaching, re-imagining teacher education. Teachers and teaching: Theory and practice, 15(2), 273-290. Retrieved from http://www.tandfonline.com/doi/pdf/10.1080/13540600902875340

Grossman, P., Loeb, S., Cohen, J., \& Wyckoff, J. (2013). Measure for measure: The relationship between measures of instructional practice in middle school English language arts and teachers' value-added scores. American Journal of Education, 119(3), 445-470. DOI: https://doi.org/10.1086/669901 
Grossman, P., \& McDonald, M. A. (2008). Back to the future: Directions for research in teaching and teacher education. American Educational Research Journal, 45(1), 184-205. DOI: https://doi.org/10.3102/0002831207312906

Hammerness, K. (2006). From coherence in theory to coherence in practice. Teachers College Record, 108(7), 1241-1265. Retrieved from

https://ed.stanford.edu/sites/default/files/from_coherence_in_theory_to_coherence_in_pra ctice.pdf

Hammerness, K., \& Klette, K. (2015). Indicators of quality in teacher education: Looking at features of teacher education from an international perspective. In A. W. Wiseman \& G. K. LeTendre (Eds.), Promoting and sustaining a quality teaching workforce (Vol. 27, pp. 239-277). Bingley, England: Emerald Group Publishing.

Hammerness, K., Williamson, P., \& Kosnick, C. (2016). Introduction to the special issue on urban teacher residencies: The trouble with "generic" teacher education. Urban Education, 51(10), 1155-1169. DOI: https://doi.org/10.1177/0042085915618723

Hiebert, J., \& Grouws, D. A. (2007). The effects of classroom mathematics teaching on students' learning. In F. K. Lester (Ed.), Second handbook of research on mathematics teaching and learning (pp. 371-404). Charlotte, NC: Information Age.

Hiebert, J., Morris, A. K., Berk, D., \& Jansen, A. (2007). Preparing teachers to learn from teaching. Journal of Teacher Education, 58(1), 47-61. DOI: https://doi.org/10.1177/0022487106295726

Holmes Group (1995). Tomorrow's schools of education. Retrieved from East Lansing, MI: http://files.eric.ed.gov/fulltext/ED399220.pdf

Janssen, F., Westbroek, H., \& Doyle, W. (2014). The practical turn in teacher education: Designing a preparation sequence for core practice frames. Journal of Teacher Education, 65(3), 195-206. DOI: https://doi.org/10.1177/0022487113518584

Kennedy, M. (1999). The role of pre-service teacher education. In L. Darling-Hammond \& G. Sykes (Eds.), Teaching as the learning profession: Handbook of teaching and policy (pp. 54-86). San Francisco, CA: Jossey Bass.

Klette, K. (2009). Challenges in strategies for complexity reduction in video studies. Experiences from the PISA+ study: A video study of teaching and learning in Norway. In T. Janì \& T. Seidel (Eds.), The power of video studies in investigating teaching and learning in the classroom (pp. 61-82). Münster, Germany: Waxmann.

Klette, K., \& Hammerness, K. (2012). Coherence and assignments in teacher education: Findings from the pilot study. Paper presented at the annual meeting of the research council, Oslo, Norway.

Kloser, M. (2014). Identifying a core set of science teaching practices: A Delphi expert panel approach. Journal of Research in Science Teaching, 51(9), 1185-1217. DOI: https://doi.org/10.1002/tea.21171

Kunzman, R. (2002). Preservice education for experienced teachers: What STEP teaches those who have already taught. Issues in Teacher Education, 11(1), 99-112.

Kvalbein, I. A. (2003). Norsk allmennlærerutdanning i et historisk perspektiv [Norwegian teacher education in a historical perspective]. In G. E. Karlsen \& I. A. Kvalbein (Eds.), Norsk læererutdanning: Søkelys på allmennlærerutdanningen i et reformperspektiv [Norwegian teacher education. Focus on teacher education in a reform perspective] (pp. 24-41). Oslo, Norway: Universitetsforlaget.

Lampert, M., Franke, M. L., Kazemi, E., Ghousseini, H., Turrou, A. C., Beasley, H., Cunard, A., \& Crowe, K. (2013). Keeping it complex: Using rehearsals to support novice teacher learning of ambitious teaching. Journal of Teacher Education, 64(3), 226-243. DOI: https://doi.org/10.1177/0022487112473837 
LeTendre, G. K., \& Wiseman, A. (Eds.). (2015). Promoting and sustaining a quality teacher workforce (Vol. 27). Bingley, UK: Emerald Group Publishing.

Lund, A., \& Eriksen, T. M. (2016). Teacher education as transformation: Some lessons learned from a center for excellence in education. Acta Didactica Norge, 10(2), 53-72. Retrieved from https://www.journals.uio.no/index.php/adno/article/view/2483/2458

Martínez, J. F., Borko, H., \& Stecher, B. M. (2012). Measuring instructional practice in science using classroom artifacts: Lessons learned from two validation studies. Journal of Research in Science Teaching, 49(1), 38-67. DOI: https://doi.org/10.1002/tea.20447

McDonald, M., Kazemi, E., \& Kavanagh, S. S. (2013). Core practices and pedagogies of teacher education: A call for a common language and collective activity. Journal of Teacher Education, 64(5), 378-386. DOI: https://doi.org/10.1177/0022487113493807

McDonald, M., Kazemi, E., Kelley-Petersen, M., Mikolasy, K., Thompson, J., Valencia, S. W., \& Windschitl, M. (2014). Practice makes practice: Learning to teach in teacher education. Peabody Journal of Education, 89(4), 500-515. DOI: https://doi.org/10.1080/0161956X.2014.938997

Moon, B. (Ed.). (2016). Do universities have a role in the education and training of teachers? An international analysis of policy and practice. Cambridge, England: Cambridge University Press.

Munthe, E., \& Haug, P. (2009). Research on teacher education in Norway 2000-2009: Trends and gaps. Paper presented at the EARLI conference, Amsterdam, The Netherlands.

Munthe, E., Malmo, K.-A. S., \& Rogne, M. (2011). Teacher education reform and challenges in Norway. Journal of Education for Teaching, 37(4), 441-450. Retrieved from http://www.tandfonline.com/doi/pdf/10.1080/02607476.2011.611012

Munthe, E., \& Rogne, M. (2016). Norwegian teacher education: Development, steering and current trends. In B. Moon (Ed.), Do universities have a role in the education and training of teachers? An international analysis of policy and practice (pp. 35-55). Cambridge, England: Cambridge University Press.

National Council for Accreditation of Teacher Education (2010). Transforming teacher education through clinical practice: A national strategy to prepare effective teachers. Report of the Blue Ribbon Panel on Clinical Preparation and Partnerships for improved student learning. Retrieved from http://www.ncate.org/LinkClick.aspx?fileticket=zzeiB1OoqPk\%3D\&tabid=7

National Regulation for Teacher Education (levels 8-13) (2013). Regulation related to Act of 1 April 2005 No. 15 about universities and university colleges [in Norwegian]. Retrieved from https://lovdata.no/dokument/SF/forskrift/2013-03-18-288

Niemi, H. (2016). Academic and practical: Research-based teacher education in Finland. In B. Moon (Ed.), Do universities have a role in the education and training of teachers? An international analysis of policy and practice (pp. 19-33). Cambridge, England: Cambridge University Press.

Norwegian Agency for Quality Assurance in Education (2006). Evaluering av allmennlcrerutdanningen i Norge 2006. Del 1: Hovedrapport [Evaluation of general teacher education in Norway 2006. Part 1: Main report]. Retrieved from http://www.nokut.no/Documents/NOKUT/Artikkelbibliotek/Norsk_utdanning/Evaluering /alueva/ALUEVA_Hovedrapport.pdf

Norwegian Government (2014). Utsetter krav om mastergrad for PPU [Postpones requirement for master's degree for PPU]. Press release. Retrieved from https://www.regjeringen.no/no/aktuelt/utsetter-krav-om-mastergrad-for-ppu/id2482527/

Orchard, J., \& Ellis, V. (2014). Learning teaching from experience: Multiple perspectives and international contexts. London, England: Bloomsbury. 
Organization for Economic Co-operation and Development (2013). Education at a Glance 2013: OECD Indicators. Retrieved from https://www.oecd.org/edu/eag2013\%20(eng)-FINAL\%2020\%20June\%202013.pdf

Organization for Economic Co-operation and Development (2014). PISA 2012 results. Retrieved from https://www.oecd.org/pisa/keyfindings/pisa-2012-results-volume-I.pdf

Paksuniemi, M. (2009). Tornion alakansakoulunopettajaseminaarin opettajakuva lukuvuosina 1921-1945 rajautuen oppilasvalintoihin, oppikirjoihin ja oheistoimintaan [The teacher image in the lower primary school teachers' college of Tornio in 1921-1945 in the light of selection of students, textbooks, and activities of leisure time]. Unpublished doctoral dissertation. University of Lapland, Rovaniemi, Finland.

Pianta, R. C., \& Hamre, B. K. (2009). Conceptualization, measurement, and improvement of classroom processes: Standardized observation can leverage capacity. Educational Researcher, 38(2), 109-119. DOI: https://doi.org/10.3102/0013189x09332374

Rasmussen, J. (2008). Nordic teacher education programmes in a period of transition: The end of a well-established and long tradition of 'seminarium'-based education. In B. Hudson \& P. Zgaga (Eds.), Teacher education policy in Europe: A voice of higher education institutions (pp. 325-344). Umeå, Sweden: University of Umeå, Faculty of Teacher Education.

Reid, J.-A. (2011). A practice turn for teacher education? Asia-Pacific Journal of Teacher Education, 39(4), 293-310. DOI: https://doi.org/10.1080/1359866X.2011.614688

Sahlberg, P. (2011). Finnish lessons: What can the world learn from educational change in Finland? New York, NY: Teachers College Press.

Stake, R. E. (2006). Multiple case study analysis. New York, NY: Guilford Press.

Stroupe, D., \& Windschitl, M. (in press). The three-story challenge: Implications of the next generation science standards for teacher preparation. Journal of Teacher Education.

Säntti, J., Rantala, J., Salminen, J., \& Hansen, P. (2014). Bowing to science: Finnish teacher education turns its back on practical schoolwork. Educational Practice and Theory, 36(1), 21-41. DOI: https://doi.org/10.7459/ept/36.1.14_03

Taylor, T. (2016). Cinderella faculties: The changing and unchanging nature of teacher education in Australian universities. In B. Moon (Ed.), Do universities have a role in the education and training of teachers? An international analysis of policy and practice (pp. 127-148). Cambridge, UK: Cambridge University Press.

Thompson, J., Windschitl, M., \& Braaten, M. (2013). Developing a theory of ambitious earlycareer teacher practice. American Educational Research Journal, 50(3), 574-615.

Retrieved from http://aer.sagepub.com/content/50/3/574.abstract

Tigchelaar, A., \& Korthagen, F. (2004). Deepening the exchange of student teaching experiences: Implications for the pedagogy of teacher education of recent insights into teacher behaviour. Teaching and Teacher Education, 20(7), 665-679. DOI: https://doi.org/10.1016/j.tate.2004.07.008

Tomarken, A. J., \& Serlin, R. C. (1986). Comparison of ANOVA alternatives under variance heterogeneity and specific noncentrality structures. Psychological Bulletin,99(1), 90-99. Retrieved from http://psycnet.apa.org/journals/bul/99/1/90.html

Uusiautti, S., \& Määttä, K. (2013). Significant trends in the development of Finnish teacher education programs (1860-2010). Education Policy Analysis Archives, 21(59), 1-22. Retrieved from http://epaa.Asu.Edu/ojs/article/view/1276

Valli, L. (1997). Listening to other voices: A description of teacher reflection in the United States. Peabody Journal of Education, 72(1), 67-88. Retrieved from http://www.jstor.org/stable/1493261 
Windschitl, M., Thompson, J., Braaten, M., \& Stroupe, D. (2012). Proposing a core set of instructional practices and tools for teachers of science. Science Education, 96(5), 878903. DOI: http://doi.org/10.1002/sce.21027

Zeichner, K. (2012). The turn once again toward practice-based teacher education. Journal of Teacher Education, 63(5), 376-382. DOI: http://doi.org/10.1177/0022487112445789

Zeichner, K., \& Conklin, H. (2005). Teacher education programs. In M. Cochran-Smith \& K. Zeichner (Eds.), Studying teacher education: The report of the AERA panel on research and teacher education (pp. 645-735). Mawah, NJ: Lawrence Erlbaum Associates.

\footnotetext{
${ }^{1}$ Norwegian Research Council funding supported the inclusion of programs from Finland, Norway, and the US. The programs from Chile and Cuba sought to participate and obtained funding for data collection and analysis. Additional programs (e.g., from Malaysia and Sweden) have joined after initial data collection. Those faculty have obtained funding to collect data in their programs.

${ }^{2}$ Several other institutions have joined post-initial data collection-Malaysia, Sweden, Estonia, and the Netherlands.

${ }^{3}$ Response rate was calculated based on the number of candidates enrolled in the specific course where the survey was distributed.

${ }^{4}$ The coding book draws on similar protocols for scoring observation data (Classroom Assessment Scoring System [CLASS]; Pianta \& Hamre, 2009; Protocol for Language Arts Teaching Observations [PLATO] 5.0), For more information, the complete coding book is published here:

http://www.uv.uio.no/ils/english/research/projects/cate/Instruments/coding-scheme-cate-observation-data.pdf ${ }^{5}$ Because the unit of our score was the whole lesson, each dimension has received only about three scores in each subject. Since the Kappa increases with an increasing number of codes (Bakeman \& Quera, 2011), we do not report the Kappa of the individual dimensions.
} 